\title{
Review on Coffee (Coffea arabica L.) Wet Processing more Focus in Ethiopia
}

\section{Hailu Duguma and Mosisa Chewaka*}

Department of Horticulture, College of Agriculture and Veterinary Science, Ambo University, Ambo, Ethiopia

*Corresponding Author: Mosisa Chewaka, Department of Horticulture, College of Agriculture and Veterinary Science, Ambo University, Ambo, Ethiopia.

Received: September 09, 2019; Published: October 11, 2019

DOI: 10.31080/ASAG.2019.03.0676

\begin{abstract}
Quality is the most important parameter in the world coffee trade, and it is determined by about $40 \%$ in the field and the rest $60 \%$ at the post-harvest ( $40 \%$ at primary, and $20 \%$ at secondary processing methods). Generally, among several factors which can affect coffee quality includes water status of the soil, climatic conditions, berries maturity at harvest and bean processing methods, agricultural (field) management and genetic properties of different cultivars. Comparing to dry processing, wet processing method can greatly improve coffee quality (both cup and physical quality) though its current status is very low. In relation to coffee processing, waste utilization (for instance, as a fertilizer, as a fuel) as well as treatment of coffee effluents before discharging to the surroundings (more specifically to the nearby rivers) can tackle the risk of environmental pollution. Because different investigators approved that the releasing of un-treated effluents and other solid by-product significantly affects the quality of river water. Particularly, effluents released to the river causes severe illnesses (overexcitement, skin irritation, stomach pain, nausea and breathing problem); can kill the micro-organisms and plants that eliminate and absorb the contamination in the water generated by the wet mill (wet processing). Thus, it needs a critical set up of west management strategies which include the way of effluent treatment before unwisely discharging to the environment and alternative west utilization opportunities.
\end{abstract}

Keywords: Coffee; Quality; West Management; Wet Processing

\section{Introduction}

Coffee is generally the most important food commodity worldwide and ranks second, after crude oil, among all commodities [1]. Among several values, coffee Coffea arabica L. is a cornerstone in the Ethiopian economy [2]; this could be because Ethiopia is the birthplace [3] of coffee Arabica. Similarly, according to [4], coffee has traditionally been the backbone of Ethiopia's economy; it is the most important agricultural product traded in the world [5].

There are predominantly two commercial coffee species and some inter-specific crosses used in coffee production; these are coffee Arabica (Coffea arabica L.) which requires a wet tropical highlands climate at altitudes between 600 and 1600m, and Robusta coffee (Coffea canephora) which can be grown at sea level but it too is often grown in wet tropical highlands. The vigour and disease resistance of Robusta is superior to Arabica [6]. Arabica coffees ( $60 \%$ of the current world coffee production) are generally sold at considerably better prices than Robustas on account of superior beverage quality [7]. In Brazil, which accounts for $40 \%$ of world production, $97.55 \%$ of coffee cultivars are derived from Typica and Bourbon which are from $C$. arabica native to Ethiopiatypically Southwestern Ethiopia that later taken to Yemen $15^{\text {th }}$ and $16^{\text {th }}$ century $[8,9]$. Later, it was gradually distributed to different parts of the world.

Among them as stated by [10], Arabica coffee is very appropriate and viable as a cash crop to replace opium (the dried latex obtained from the Opium poppy, Papaver somniferum) in the highlands 
of Thailand; and it has been introduced since 1849 [11]. On the other hand, one of the major challenges the Ethiopian coffee sector is facing is that many coffee producers, mostly from the eastern part of the country are replacing coffee with khat (Catha edulis) a plant with stimulant properties [12,13]. The GAIN report justified that the Khat plant can withstand drought, diseases and pests; and can also be harvested three to four times a year and provides better revenue for farmers than other cash crops such as vegetables, oil crops or even coffee.

Numerous factors affect coffee quality including soil water status, climatic conditions, maturity of coffee berries at harvest and bean processing (fermentation, washing, drying, storage, roasting, beverage preparation), agricultural management (shade, pruning, fertilization) and genetic properties of cultivars [14]. As value addition to coffee, primary processing including selective harvesting, proper drying to the standard moisture level on clean drying area (raised bed, cemented floor, etc.), washed coffee processing and proper storage can enormously increase the quality of coffee that could fetch premium price [15]. Therefore, the objective of this study is to review the status and the effect of wet processing method for Arabica coffee.

\section{Processing}

Coffee processing could be either wet or dry methods, which vary in complexity and expected quality of the coffee [16]. About $40 \%$ of the world coffee is processed according to the wet method, including most of the organically produced coffees. Washed coffees are generally of superior quality, although certain Ethiopian or Brazilian dry-processed Arabicas are much sought after for their specific taste and flavour [17]. Quality is the most important parameter in the world coffee trade, and it is determined by $40 \%$ in the field, $40 \%$ at the post-harvest (Fig. below) primary processing, and $20 \%$ at secondary processing. Washed coffee accounts about $29 \%$ while unwashed 71\% in Ethiopia. This underscores the importance of primary processing in enhancing the quality and value of coffee [18]. Similarly [19] stated that Ethiopian coffee is processed and exported in two processing techniques, namely, natural sun-dried $(70 \%)$ and washed (30\%) coffees. Wet processed (Washed) coffee is being sold in international markets with a premium of more than $20 \%$ however only about $30 \%$ of Ethiopia's coffee export is washed [20]. Coffee quality is affected by pre and post harvest practices among which processing method and roasting duration is the main ones [2] applied after harvest.

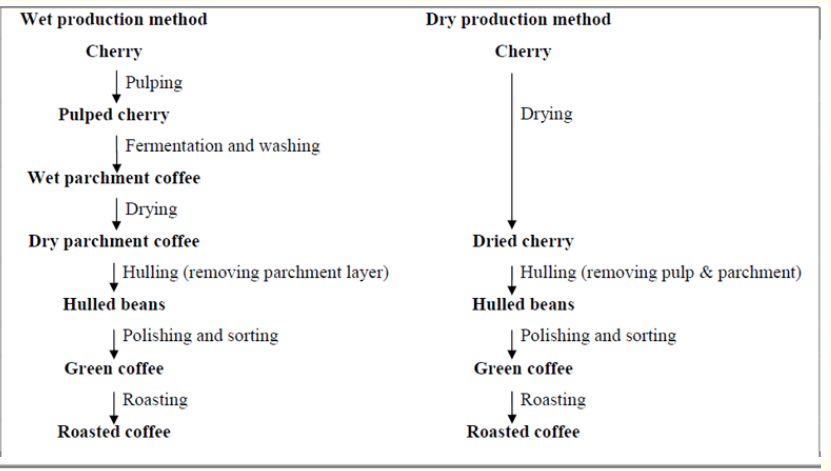

Figure 1: The different stages in postharvest processing of coffee beans (Source: Chapangain and Hoekstra, 2003).

It is known that wet processed Arabica coffee has higher demand and fetches better price in the world market though the conventional processing practice has apparently caused contamination of rivers in regions where wet processing is intensively practiced [4]. Arabica coffee in Thailand which is mainly grown in the highlands at approx. 800 masl is wet processed to give high quality green bean. In this region, the Catimor cultivar is recommended as it is rust resistant [10].

\section{Effect of processing methods on final quality}

Processing method, variety and roast duration affect cup quality of coffee [2]. These authors put as a recommendation that at fixed temperature $(200 \mathrm{oC})$ and moisture content $(11 \%)$ roasting dry and wet processed coffee for six and eight minutes respectively, and six to eight minutes for semi washed coffee is advisable. The author [21] found that in washed (wet processed) coffee beans, only low amounts of sugars (particularly fructose and glucose) were present, whereas in unwashed (dry processed) coffees the contents of sugars were significantly higher.

In the wet processing method, Velmourougane [22] reported that underwater soaking improve raw and liquor quality of coffee due to the leaching away of chemical compounds such as diterpenes, polyphenols, tannins, etc. which are responsible for bitterness and browning of coffee beans. Similarly, two-stage fermentation (underwater soaking following 'dry' fermentation) enhances the appearance of both raw and roast coffees compared to 'dry' fermentation only Behailu., et al. [23]. On the other hand, as shown 
in table below, the method of removing the mucilage (dry fermentation, under water fermentation, peptic-enzyme accelerated fermentation, or chemical cleaning) has no effect on the liquor quality and there is no evidence that only one method can produce significantly better liquors than the other [24].

\begin{tabular}{|l|c|c|c|}
\hline $\begin{array}{l}\text { Types of fer- } \\
\text { mentation }\end{array}$ & Acidity & Body & Flavor \\
\hline $\begin{array}{l}\text { Two-stage } \\
\text { fermentation 16 } \\
\text { hrs+24 hrs soak }\end{array}$ & $\begin{array}{c}\text { Light-medi- } \\
\text { um }^{+}\end{array}$ & $\begin{array}{c}\text { Medium to } \\
\text { light medium }\end{array}$ & $\begin{array}{c}\text { Fair/Good to } \\
\text { fair average } \\
\text { quality (FAQ) }\end{array}$ \\
\hline $\begin{array}{l}\text { Under water } \\
\text { fermentation 16 } \\
\text { hrs+24hrs soak }\end{array}$ & $\begin{array}{c}\text { Medium to } \\
\text { light medium }\end{array}$ & $\begin{array}{c}\text { Medium to } \\
\text { light medium }\end{array}$ & Fair/Good \\
\hline $\begin{array}{l}\text { NaOH- } \\
\text { cleaned+40 hrs } \\
\text { soak }\end{array}$ & $\begin{array}{c}\text { Medium to } \\
\text { light medium }\end{array}$ & $\begin{array}{c}\text { Medium to } \\
\text { light medium }\end{array}$ & $\begin{array}{c}\text { Fair/Good to } \\
\text { FAQ }\end{array}$ \\
\hline
\end{tabular}

Table 1: Liquor quality of dry fermented, under-water fermented and $\mathrm{NaOH}$-cleaned coffee.

Source: Brownbridge and Michael (1971).

\section{Advantage of coffee by-product}

More than $50 \%$ of the coffee fruit is discarded as by-product during green coffee processing; so far, most progress has been achieved in industrial application of the by-product other than food industry, such as energy production, adsorption of compounds and manufacturing of industrial products, such as particleboards, ethanol, gibberellic acid and $\alpha$-amylase [1]. Also these authors included that the coffee husks, peel and pulp, which comprises nearly $45 \%$ of the cherry, are one of the main by-products of coffee agro-industry and might be a valuable material for several purposes, including extraction of caffeine and polyphenols.

The use of coffee parchment flour in cookies may increase the availability of functional ingredients that is a source of dietary fiber for bakery products, add economic value to coffee processing by-products and decrease environmental impacts due to the high amounts of waste generated by coffee processing mills [25]. Similarly, according to [7], in coffee-curing plants, the parchment hulled from the green beans usually serves as fuel for the boilers.

According to [26,27], coffee processing by-products have promising potential for renewable energy production like anaerobic conversion and briquette/pellets; this can alleviate the risk of environmental burden. The finding of [28] revealed an existence of ma- jor gap in waste utilization of the coffee industries however spent coffee grounds as well as coffee silver skin has great potential as a horticultural fertilizer which can be a part of solutions intended for eco-toxicological and environmental impacts of coffee waste.

Impact of effluents and by-products from wet coffee processing plants

Chemical compounds such as caffeine, tannins and chlorogenic acid present in coffee by-products having eco-toxicological worry which can also limit their value-adding applications [28]. The result of [29-31] study has clearly indicated that the water quality of the river was significantly affected by the discharge of un-treated effluents and by-product from coffee washed plants. Hence, they suggested urgent intervention towards effluent management options to avoid further needless damage to the environment.

Coffee wet processing generally generates two byproducts such as coffee pulp and wastewater (known as honey water or effluent); this wastewater is acidic, which kills the micro-organisms and plants that eliminate and absorb the contamination in the water generated by the wet mill [32]. Coffee effluent is being directly discharged to the nearby water bodies causing severe ailments like overexcitement, skin irritation, stomach pain, nausea and breathing problem [33]. There could also be socio-economic impacts mainly due to human health problems and loss of biodiversity [30].

\section{Conclusion and Recommendation}

Wet processing can improve coffee quality. On top of this, the utilization of waste (by-product from coffee processing), for instance, as a fertilizer is another advantage that can also reduces the risk of environmental contamination. Also, coffee effluents must be treated before discharging to the nearby rivers. Hence, critical planning of west management alternative strategies is recommendable as future line of work if coffee quality improvement is intended through the use of wet processing method and scaling up its percentage. So, this planning should include west management strategies which will make possible a chance of west utilization in general and effluent treatment.

\section{Bibliography}

1. Esquivel P and Jimenez VM. "Functional properties of coffee and coffee by-products". Food Research International (2011).

2. Abrar Sualeh., et al. "Processing Method, Variety and Roasting Effect on Cup Quality of Arabica Coffee (Coffea arabica L.)". Discourse Journal of Agriculture and Food Sciences 2 (2014): 70-75. 
3. ICO, International Coffee Organization. ANNUAL REVIEW: the 4th World Coffee Conference, Addis Ababa, Ethiopia (2016).ss

4. Solomon E., et al. "The Need for Eco-Friendly Processing of Coffee in Southwestern Ethiopia: Policy Implications and Recommendations for Cleaner Production at the Birth Place of Arabica Coffee". Ethiopian Institute of Agricultural Research (EIAR), Jimma, Ethiopia (2008).

5. Chapagain AK and Hoekstra AY. "The Water Needed to Have the Dutch Drink Coffee; Value of Water Research Report Series; UNESCO-IHE: Delft". The Netherlands 14 (2003).

6. ICO, International Coffee Organization. Guidelines for the Prevention of Mould Formation in Coffee (2006).

7. Herbert van der Vossen., et al. "Next generation variety development for sustainable production of Arabica coffee (Coffea arabica L.): a review". Euphytica 204 (2015): 243-256.

8. World Coffee Research. Arabica Coffee Varieties. 10940 SW Barnes Rd \#334, Portland, OR 97225, worldcoffeeresearch. org (2018).

9. Bossolasco L. "A study case on coffee (Coffea arabica L.): Limu coffee" (2009).

10. Angkasith P. "Coffee Production Status and Potential of Organic Arabica Coffee in Thailand". Proc. 1st Asian Regional Roundtable on Sustainable, Organic and Speciality Coffee Production, Processing and Marketing, (2001): 26-28.

11. Noppakoonwong Uthai., et al. "Research and Development of Arabica Coffee in Thailand". Available: 25th International Conference on Coffee Science (ASIC) (2015).

12. GAIN-Global Agricultural Information Network. Coffee Annual Report, GAIN Report Number: ET 1402. USDA Foreign Agricultural Service. Coffee Annual, Addis Ababa, Ethiopia (2014).

13. GAIN-Global Agricultural Information Network. Coffee Annual Report, GAIN Report Number: ET 1904. USDA Foreign Agricultural Service. Coffee Annual, Addis Ababa, Ethiopia (2019).

14. Philippe Vaast., et al. "Fruit thinning and shade improve bean characteristics and beverage quality of coffee (Coffea arabica L.) under optimal conditions". Journal of the Science of Food and Agriculture 86 (2016): 197-204.
15. Bayetta Bellachew. "A quick assessment of coffee production status in Cameroon: a brief report (Field Travel Report No.9)". Inter African Coffee Organization (IACO), African Coffee Research Network (ACRN), BP: V210, Abidjan, Cote d'Ivoire (2012).

16. Wringley G. "Tropical Agricultural Series". Jogn Wiley and Sons. Inc., New York (1988): 464-465.

17. Van Der Vossen HAM. "A Critical Analysis of the Agronomic and Economic Sustainability of Organic Coffee Production". Experimental Agriculture 41 (2005): 449-473.

18. Rechard Musebe., et al. "Primary coffee processing in ethiopia: patterns, constraints and determinants". African Crop Science Conference Proceedings 8 (2017): 1417-1421.

19. Taye Kufa. "Environmental sustainability and coffee diversity in Africa". ICO World Coffee Conference (2010).

20. Tamru S and B Minten. "Value addition and processing by farmers in developing countries: evidence from the coffee sector in Ethiopia”. Invited poster at the 5th International Conference of the African Association of Agricultural Economists, 23-26 September 2016, Addis Ababa (2016).

21. Sven Knopp., et al. "Influence of processing on the content of sugars in green Arabica coffee beans". European Food Research and Technology 223 (2005): 195-201.

22. Velmourougane K., et al. "Management of Aspergillus ochraceus and Ochratoxin-A contamination in coffee during onfarm processing through commercial yeast inoculation". Biological Control 57 (2011): 215-221.

23. Behailu W/Senbet., et al. "Coffee processing and quality research in Ethiopia”. In: Girma Adugna, Bayetta Belachew, Tesfaye Shimber, Endale Taye and Taye Kufa (eds.). Coffee Diversity and Knowledge. Proceedings of a National Workshop Four Decades of Coffee Research and Development in Ethiopia, 1417 August 2007, Addis Ababa, Ethiopia (2008): 307-316.

24. Brownbridge JM and Michael S. "Coffee Processing Research in Ethiopia: Fermentation and its effect on liquor quality". Kenya Coffee (1971): 209.

25. Elba C., et al. "Coffee Berry Processing By-Product Valorization: Coffee Parchment as a Potential Fiber Source to Enrich Bakery Goods". Journal of Food, Nutrition and Population Health 1.2 (2017): 12. 
26. Asrat Gebremariam Woldesenbet., et al. "Bio-ethanol production from wet coffee processing waste in Ethiopia". Springer Plus 5 (2016): 1903.

27. Bilhate Chala Sajid Latif and Joachim Müller. "Potential of by-products from primary coffee processing as source of bio-fuels". Universität Hohenheim, Institute of Agricultural Engineering, Tropics and Subtropics Group (440e), Stuttgart, 70599, Germany (2015).

28. Brendan Janissen and Tien Huynh. "Chemical composition and value-adding applications of coffee industry byproducts: A review". Resources, Conservation and Recycling 128 (2018): 110-117.

29. Asrat Gebremariam Woldesenbet., et al. "Wet Coffee Processing Waste Management Practice in Ethiopia". Asian Journal of Science and Technology 6 (2015): 1467-1471.

30. Minuta T and Jini D. "Impact of effluents from wet coffee processing plants on the Walleme river of Southern Ethiopia". Research Journal of Environmental Toxicology 11 (2017): 90-96.

31. Dejen YT., et al. "Effect of Coffee Processing Plant Effluent on the Physicochemical Properties of Receiving Water Bodies, Jimma Zone Ethiopia". American Journal of Environmental Protection 4.2 (2015): 83-90.

32. UTZ. IMPROVED ENVIRONMENT: Manual for the construction of wastewater treatment systems in small coffee processing plants (2015).

33. Asrat Gebremariam Woldesenbet., et al. "Characteristics of Wet Coffee Processing Waste and Its Environmental Impact in Ethiopia". International Journal of Research in Engineering and Science (IJRES) 2 (2014): 01-05.

Volume 3 Issue 11 November 2019

(C) All rights are reserved by Hailu Duguma and Mosisa Chewaka. 